\title{
Effects of rivastigmin tartarat in the therapy of patients with schizophrenia
}

\author{
Snezana Djordjevic ${ }^{*}$, Snezana Japalak, Vera Vidojevic \\ From $1^{\text {st }}$ International Congress on Neurobiology and Clinical Psychopharmacology and European \\ Psychiatric Association Conference on Treatment Guidance \\ Thessaloniki, Greece. 19-22 November 2009
}

\section{Background}

Rivastigmin tartarat is a dual, reversible cholinesterase inhibitor (acetil and butril). Its chemical composition is (S)-N-ethyl-N-methyl-3-1-dimethylamin - ethyl-phenyl carbamat hydrogen-(2R,3R)-tartrat. FDA has approved its use in treatment of Alzheimer dementia and dementia in combination with Parkison disease. In addition to this, results based on small clinical studies and case reports showed positive efects of rivastigmin tartarat in therapy applied in numerous pyschiatric disorders.

\section{Materials and methods}

In this study 11 patients have been observed. According to ICD-10 they all satisfied criteria for diagnosis of residual schizophrenia and had a score of below 24 at MMSE and high scores at NPI 12 and BPRS. During the period of 60 days, apart from antipsychotics and anxiolitics or psychostabilisers, patients also received rivastigmin tartarat in their therapy.

\section{Results}

The study showed that rivastigmine therapy produced significant improvements when it comes to cognition and reduction of disorders in the sphere of afectivebehavioristic functioning of patients with residual schizophrenia. However, this interpretation cannot be confirmed to be completely valid due to the size of treated group, the absence of the control group, and the length of the observing period.

\section{Conclusions}

Dual cholinesterase inhibitors (Ach and BuCh) may produce improvement in cognition and behavioural performances, as well as the general quality of life with patients diagnosede with residual schizophrenia. Future studies applied on this kind of patients should precisely explain the basic farmachological mechanisams of rivastigmin tartarat, and approve/disapprove the results of clinical studies and case reports that have been preformed so far.

Published: 22 April 2010

\section{References}

1. Hussain M, Chaudry A, Hussain S: Rivastigmine tartrate in treatment of neurocognitive deficits in clozapine treated schizophrenics. Poster presented at the 51st Annual Meeting of the Canadian Psychiatric Association, Montreal, Canada, 15-19 November 2001

2. Stryjer R, Strous RD, Bar F, et al: Beneficial effect of rivastigmin augmentation for the management of comorbid schizophrenia and dementia. Clin Neuropharmacol 2003, 26:12-17.

3. Alessandro Lenzi, et al: Effects of Rivastigmine on Cognitive Function and Quality Of Life in Patients With Schizophrenia. Clinical Neuropharmacology Lippincott Williams \& Wilkins, Inc 2003, 26(6):317-321.

4. Enz A, Boddeke H, Gray J, et al: Pharmacologic and clinicopharmacologic properties of SDZ ENA 713, a centrally selective acetylacetylcholin esterase inhibitor. Ann N Y Acad Sci 1991, 640:272-5.

doi:10.1186/1744-859X-9-S1-S91

Cite this article as: Djordjevic et al:: Effects of rivastigmin tartarat in the therapy of patients with schizophrenia. Annals of General Psychiatry 2010 9(Suppl 1):S91.

Submit your next manuscript to BioMed Central and take full advantage of:

- Convenient online submission

- Thorough peer review

- No space constraints or color figure charges

- Immediate publication on acceptance

- Inclusion in PubMed, CAS, Scopus and Google Scholar

- Research which is freely available for redistribution 